\title{
Hubungan Pola Asuh Orang Tua Dengan Tingkat Keberhasilan Toilet Training Pada Anak Usia 18-36 Bulan
}

\author{
Eka Sarofah Ningsih \\ Program Studi D III Kebidanan Universitas Islam Lamongan \\ Email: ekahp88@yahoo.com
}

\begin{abstract}
ABSTRAK
Toilet training pada anak merupakan suatu usaha untuk melatih anak agar mampu mengontrol dalam melakukan buang air kecil atau buang air besar. Ibu yang tidak menerapkan toilet training sejak dini akan membuat orang tua semakin sulit untuk mengajarkan pada anak ketika anak bertambah usianya, anak tidak mandiri dan masih membawa kebiasaan mengompol hingga besar.

Penilitian ini ingin membuktikan apakah ada hubungan antara pola asuh orang tua dengan tingkat keberhasilan toilet training pada anak usia 18-36 bulan di Desa Tanjung Kecamatan Lamongan Kabupaten Lamongan. Penelitian ini merupakan penelitian analitik korelasional dengan menggunakan observasi. Populasi dalam penelitian ini sebanyak 43 responden dengan menggunakan teknik total populasi. Variabel yang diukur adalah pola asuh orang tua sebagai variabel independen, sedangkan variabel dependenya keberhasilan toilet training pada anak usia 18-36 bulan.

Hasil yang didapatkan dari penelitian ini sebagian besar orang tua menggunakan pola asuh demokratis, sedangkan tingkat keberhasilan toilet training sebagian besar anak sudah bisa melakukan toilet training dengan baik. Uji Statistik yang di gunakan dalam penelitian ini adalah uji statistik Non Parametrik Uji Chi Square didapatkan $X^{2}$ hitung $=19,04$ dan $p$ value $=0.000$ dimana $p<0,05$ maka $\mathrm{H}_{0}$ ditolak sehingga $\mathrm{H}_{1}$ diterima yang artinya ada hubungan antara pola asuh orang tua dengan tingkat keberhasilan toilet training pada anak usia 18-36 bulan. Diharapkan ibu selalu melatih anaknya dalam toilet training dan menggunakan pola asuh yang tepat agar tingkat keberhasilan toilet training dapat tercapai.
\end{abstract}

Kata Kunci : Pola Asuh, Toilet Training, anak usia 18-36 bulan

\section{PENDAHULUAN}

Pola pengasuhan (parenting) atau perawatan anak sangat bergantung pada nilai-nilai yang dimiliki keluarga (Supartini, 2002). Pola asuh merupakan proses dari tindakan yang mempunyai tujuan untuk dicapai sedang masa tersebut dimulai dari masa kehamilan (Wong, 2003).

Toilet training pada anak merupakan suatu usaha untuk melatih anak agar mampu mengontrol dalam melakukan buang air kecil atau buang air besar. Toilet training secara umum dapat dilaksanakan pada setiap anak yang sudah mulai memasuki fase kemandirian pada anak. Fase ini biasanya pada anak usia 18-36 bulan. Dalam melakukan toilet training ini, anak membutuhkan persiapan fisik, psikologis maupun intelektualnya. Dari persiapan tersebut anak dapat mengontrol buang air besar dan buang air kecil secara mandiri (Hidayat, 2005).

Umumnya pengajaran toilet training yang dilakukan oleh orang tua yaitu $31 \%$ orang tua mulai mengajarkan pada usia anak 18-22 bulan, $27 \%$ mulai di usia 23-27 bulan, dan $16 \%$ di usia $28-32$ bulan dan $22 \%$ di usia 32 bulan ke atas. Orang tua menunggu anak siap untuk diajarai toilet training sehingga dalam pengajaran tidak membutuhkan waktu yang lama (Warner, 2007). 
Berdasarkan penelitian di Jawa Timur oleh Juniati, tahun 2014 di ketahui pada 430 anak usia toddler (12-36 bulan) 56\% masih mengompol di celana dan diketahui anak baru bicara setelah celana yang dikenakan basah. Penelitian di Surabaya (2006) menunjukkan bahwa batita belum bisa menggunakan otot mereka untuk mengontrol keinginan untuk ke belakang hingga berusia paling tidak 18 bulan. Bahkan beberapa ahli menganggap bahwa anak umur enam tahun masih mengompol itu wajar, walaupun itu hanya dilakukan oleh sekitar $12 \%$ anak umur 6 tahun (Juniati, 2014). Akan tetapi, bukan berarti anak tidak diajarkan bagaimana cara yang benar untuk buang air kecil (BAK) dan buang air besar (BAB) yang benar dan di tempat yang tepat (Maryunani, 2013).

Penyebab gagalnya toilet training pada anak salah satunya disebabkan oleh pola asuh orang tua dalam mengasuh anak. Banyak orang tua yang kurang memiliki kesabaran ekstra dalam melatih toilet training, sehingga tujuan dari toilet training sendiri tidak terwujud (Warner, 2007).

Dampak yang paling umum dalam kegagalan toilet training seperti adanya perlakuan atau aturan yang ketat bagi orang tua kepada anaknya yang dapat mengganggu kepribadian anak dimana anak cenderung minder dan tidak percaya diri, bersikap keras kepala dan kikir. Hal ini dapat ditunjukkan oleh orang tua yang sering memarahi anak pada saat buang air kecil maupun besar atau melarang anak untuk buang air kecil maupun besar saat berpergian (Istichomah, 2009).

Solusinya adalah menciptakan kedekatan interaksi orang tua dengan anak dalam toilet training, ini akan membuat anak merasa aman dan percaya diri (Fathi, 2011).

Berdasarkan fenomena diatas, dimana masih banyak ibu yang tidak menerapkan toilet training. Atas dasar hal tersebut, peneliti dapat melaksanakan suatu penelitian serta diharapkan membawa manfaat bagi responden, maka peneliti tertarik untuk mengungkap tentang "Hubungan Pola Asuh Orang Tua Dengan Tingkat Keberhasilan Toilet Training Pada Anak Usia 18-36 Bulan di Desa Tanjung Kecamatan Lamongan Kabupaten Lamongan"

\section{TUJUAN}

Mengetahui hubungan pola asuh orang tua dengan tingkat keberhasilan toilet training pada anak usia 18-36 bulan di Desa Tanjung Kecamatan Lamongan Kabupaten Lamongan.

\section{MANFAAT}

Dengan melakukan penelitian ini diharapkan agar pembelajaran toilet training dapat diterapkan sejak dini pada bayi usia 18-36 bulan melalui pola asuh orang tua.

\section{METODE PENELITIAN}

Penelitian ini ingin membuktikan apakah ada hubungan antara pola asuh orang tua dengan tingkat keberhasilan toilet training pada anak usia 18-36 bulan di Desa Tanjung Kecamatan Lamongan Kabupaten Lamongan. Rancangan yang digunakan cross sectional. Berdasarkan tujuan penelitian termasuk rancangan penelitian analitik korelation. Berdasarkan sumber data termasuk jenis data primer (Arikunto, 2006).

Sampel penelitian ini yaitu seluruh ibu dan anaknya yang berusia 18-36 bulan di desa Tanjung kecamatan Lamongan kabupaten Lamongan sebanyak 43 orang, dengan menggunakan teknik total populasi. Variabel yang diukur adalah pola asuh orang tua sebagai variabel independen, sedangkan variabel dependenya keberhasilan toilet training pada anak usia 18-36 bulan.

\section{HASIL PENELITIAN}

\section{Data Umum}

1.1 Distribusi Frekuensi Umur Ibu

Tabel 1.1 Distribusi frekuensi umur ibu yang jadi responden di Desa Tanjung Kecamatan 


Lamongan $\quad$ Kabupaten
Lamongan

\begin{tabular}{ccc}
\hline Umur (tahun) & Frekuensi & $\begin{array}{c}\text { Presentase } \\
(\mathbf{\%})\end{array}$ \\
\hline Dewasa awal & 2 & 4,7 \\
Dewasa & 36 & 83,7 \\
Dewasa Akhir & 5 & 11,6 \\
\hline Jumlah & 43 & 100 \\
\hline
\end{tabular}

Hal ini disebabkan karena umur yang lebih dewasa mempunyai pola pikir yang lebih matang dari dewasa awal, sehingga berpengaruh pada pola asuh orang tua.

\subsection{Distribusi Frekuensi Umur Anak}

Tabel 1.2 Distribusi frekuensi umur anak yang jadi responden di Desa Tanjung Kecamatan Lamongan Kabupaten Lamongan

\begin{tabular}{ccc}
\hline Umur (bulan) & Frekuensi & $\begin{array}{c}\text { Presentase } \\
(\mathbf{\%})\end{array}$ \\
\hline 18-24 bulan & 13 & 30,2 \\
25-36 bulan & 30 & 69,8 \\
\hline Jumlah & 43 & 100 \\
\hline
\end{tabular}

Anak umur 25-36 bulan lebih paham dan mengerti tentang toilet training dari pada anak umur 18-24 bulan

1.3 Distribusi Frekuensi Pendidikan

Tabel 1.3 Distribusi frekuensi pendidikan ibu yang jadi responden di Desa Tanjung Kecamatan Lamongan Kabupaten Lamongan

\begin{tabular}{ccc}
\hline Pendidikan & Frekuensi & $\begin{array}{c}\text { Persentase } \\
(\%)\end{array}$ \\
\hline Dasar & 3 & 7 \\
Menengah & 31 & 72,1 \\
Tinggi & 9 & 20,9 \\
\hline Jumlah & 43 & 100 \\
\hline
\end{tabular}

Hal ini disebabkan karena pendidikan yang di wajibkan pemerintah adalah sampai sekolah menengah pertama

\subsection{Distribusi Frekuensi Pekerjaan}

Tabel 1.4 Distribusi frekuensi pekerjaan ibu yang jadi responden di Desa Tanjung Kecamatan

\begin{tabular}{lcc} 
& $\begin{array}{c}\text { Lamongan } \\
\text { Lamongan }\end{array}$ & Kabupaten \\
\hline \multicolumn{1}{c}{ Pekerjaan } & Frekuensi & $\begin{array}{c}\text { Presentase } \\
(\%)\end{array}$ \\
\hline Karyawan & 7 & 16,3 \\
Petani & 9 & 20,9 \\
Ibu Rumah & 20 & 46,5 \\
Tangga & 5 & 11,6 \\
Pedagang & 2 & 4,7 \\
PNS & & \\
\hline Jumlah & 43 & 100 \\
\hline
\end{tabular}

Hal ini disebabkan karena keterbatasan yang dimiliki responden.

1.5 Distribusi Frekuensi Jenis Kelamin Anak

Tabel 1.5 Distribusi frekuensi jenis kelamin anak yang jadi responden di Desa Tanjung Kecamatan Lamongan Kabupaten Lamongan

\begin{tabular}{ccc}
\hline Paritas & Freukensi & Persentase(\%) \\
\hline Laki-laki & 19 & 44,2 \\
Perempuan & 24 & 55,8 \\
\hline Jumlah & 43 & 100 \\
\hline
\end{tabular}

Hal ini disebabkan karena perempuan lebih paham dalam memberikan pola asuh pada anak khususnya tentang keberhasilan toilet training

\section{Data khusus}

\subsection{Distribusi Frekuensi Pola Asuh}

Tabel 2.1 Distribusi frekuensi Pola Asuh ibu yang jadi responden di Desa Tanjung Kecamatan Lamongan Kabupaten Lamongan

\begin{tabular}{lcc}
\hline \multicolumn{1}{c}{ Kriteria } & Frekuensi & Prosentase $(\%)$ \\
\hline Pola Asuh & 1 & 2,3 \\
Penelantar & & 20,9 \\
Pola Asuh & 9 & 20,9 \\
$\begin{array}{l}\text { Permisif } \\
\text { Pola Asuh }\end{array}$ & 9 & 55,8 \\
$\begin{array}{l}\text { Otoriter } \\
\text { Pola Asuh } \\
\text { Demokatis }\end{array}$ & 24 & 100 \\
\hline \multicolumn{1}{c}{ Jumlah } & 43 & \\
\hline
\end{tabular}

Hal ini disebabkan karena keberhasilan orang tua dalam memberikan pola asuh.

2.2 Distribusi $\quad$ Frekuensi
keberhasilan toilet training


Tabel 2.2 Distribusi frekuensi Tingkat keberhasilan anak yang jadi responden di Desa Tanjung Kecamatan Lamongan Kabupaten Lamongan

\begin{tabular}{lcc}
\hline \multicolumn{1}{c}{ Kriteria } & Frekuensi & Prosentase(\%) \\
\hline Tidak Bisa & 0 & 0 \\
Kurang bisa & 17 & 39,5 \\
Bisa & 26 & 60,5 \\
\hline Jumlah & 43 & 100 \\
\hline
\end{tabular}

Hal ini dipengaruhi oleh pola asuh yang diberikan oleh orang tua dan usia anak yang sebagian besar berumur 26-38 bulan.

2.3 Tabulasi silang hubungan pola asuh orang tua dengan tingkat keberhasilan toilet training pada anak usia 18-36 bulan di Desa Tanjung Kecamatan Lamongan Kabupaten Lamongan

\begin{tabular}{|c|c|c|c|c|c|c|c|}
\hline \multirow[b]{2}{*}{ Pola Asuh } & \multicolumn{6}{|c|}{ Keberhasilan Toilet Training } & \multirow{2}{*}{ Total } \\
\hline & $\begin{array}{c}\text { Tidak } \\
\text { bisa }\end{array}$ & $\%$ & $\begin{array}{c}\text { Kurang } \\
\text { bisa }\end{array}$ & $\%$ & Bisa & $\%$ & \\
\hline $\begin{array}{l}\text { Pola Asuh } \\
\text { Penelantar }\end{array}$ & 0 & 0 & 1 & 2,3 & 0 & 0 & 1 \\
\hline $\begin{array}{l}\text { Pola Asuh } \\
\text { Permisif } \\
\end{array}$ & 0 & 0 & 8 & 18,6 & 1 & 2,3 & 9 \\
\hline $\begin{array}{l}\text { Pola Asuh } \\
\text { Otoriter }\end{array}$ & 0 & 0 & 5 & 116 & 4 & 9,3 & 9 \\
\hline $\begin{array}{l}\text { Pola Asuh } \\
\text { Demokratis }\end{array}$ & 0 & 0 & 3 & 7,0 & 21 & 48,8 & 24 \\
\hline Total & 0 & 0 & 17 & 39,5 & 26 & 60,5 & 43 \\
\hline
\end{tabular}

\subsection{Analisa Hubungan}

Berdasarkan data diatas, dapat diketahui uji Chi Square terdapat hubungan antara variabel independen dan dependen namun hasil analisis didapatkan $50 \%$ sel yang memiliki nilai $\mathrm{Fh}<5$, sehingga uji tersebut tidak memenuhi syarat, maka harus di uji lagi menggunakan uji statistik Fisher Exact didapatkan $\mathrm{X}^{2}$ hitung $=19,004$ dan $p$ value $=0.000$ dimana $p<0,05$ maka $\mathrm{H}_{0}$ ditolak sehingga $\mathrm{H}_{1}$ diterima yang artinya ada hubungan pola asuh orang tua dengan tingkat keberhasilan toilet training pada anak usia 18-36 bulan.

Berdasarkan hasil nilai koeefisien kontingesi sebesar 0.554 menunjukkan hubungan antara pola asuh dengan keberhasilan toilet training yang dilakukan orang tua pada anak usia 18 - 36 bulan di Desa Tanjung Kecamatan Lamongan Kabupaten Lamongan mempunyai hubungan erat dan arah korelasi positif.

\section{PEMBAHASAN}

1. Mengidentifikasi pola asuh yang dilakukan orang tua pada anak usia 18 36 bulan di Desa Tanjung Kecamatan Lamongan Kabupaten Lamongan

Berdasarkan hasil penelitian diketahui bahwa sebagian besar responden memiliki pola asuh demokratis sebanyak 24 ibu (55,8\%). Dari berbagai hasil penelitian ditemukan bahwa orang tua kecenderungan menerapkan pola asuh demokratis dan memiliki pandangan persamaan hak antara orang tua dengan anak cenderung mempunyai kepribadian tinggi dan membuat anak lebih percaya diri menghadapi kehidupan. Sedangkan perlindungan yang berlebihan dari orang tua (Pola asuh permisif) akan membuat anak menjadi manja menghadapi tantangan hidup.

Hasil penelitian yang menujukkan pola asuh demokratis lebih dominan dari pada pola asuh yang lain membuktikan bahwa terdapatnya hubungan yang harmonis antara anak dan orang tua sehingga tercipta saling pengertian dan keterbukaan. Anak bebas bereskpresi dan mengemukakan kemauan serta pendapat mereka dengan terbuka (Gunarsa, 2008).

Menurut teori yang diungkapkan oleh Edwards (2006) pola asuh dapat dipengaruhi oleh beberapa faktor antara lain pendidikan orang tua, status sosial ekonomi dan jumlah anak dalam keluarga. Hal ini sesuai dengan data hasil penelitian yang didapatkan. Bahwa pendidikan orang tua yang tinggi dapat mempengaruhi penerapan pola asuh orang tua dirumah. Dari data didapatkan sebagian besar responden masih berpendidikan menengah dan 3 orang berpendidikan SD menunjukkan masih banyak orang tua yang membutuhkan akses informasi lebih 
untuk menambah pengetahuannya tentang penerapan pola asuh yang baik. Pendidikan yang dimiliki orang tua berperan dalam kesiapan mereka dalam menjalankan peran pengasuhan. Kesiapan tersebut antara lain: orang tua terlibat aktif dalam kehidupan anak, mengamati segala sesuatu dengan berorientasi pada anak (Supartini, 2004). Berdasarkan jawaban responden yang memiliki tingkat pendidikan tinggi cenderung menerapkan pola asuh demokratis dibandingkan yang tingkat pendidikan rendah (SD). Hal ini sesuai dengan teori yang diungkapkan oleh Edwards (2006) bahwa orang tua dengan latar belakang pendidikan yang tinggi dalam praktek pola asuhnya tampak sering membaca artikel ataupun mengikuti kemajuan mengenai perkembangan anak.

Banyaknya orang tua di Desa Tanjung Kecamatan Lamongan Kabupaten Lamongan menerapkan pola asuh demokratis bisa disebabkan oleh pekerjaan ibu sebagai ibu rumah tangga sehingga banyak waktu yang diluangkan untuk mendidik anak. Menurut Supartini (2004) pekerjaan ibu dapat berpengaruh terhadap penerapan pola asuh orang tua.

2. Mengidentifikasi tingkat keberhasilan toilet training anak usia 18 - 36 bulan di Desa Tanjung Kecamatan Lamongan Kabupaten Lamongan.

Berdasarkan hasil penelitian sebagian besar anak bisa melakukan toilet training yaitu sebanyak 26 anak $(60,5 \%)$. Meggit (2013) menyatakan bahwa Semakin tinggi pendidikan seseorang maka ia akan mudah menerima hal-hal baru dan mudah menyesuaikan dengan hal yang baru tersebut. Dari hasil penelitian tersebut, dapat disimpulkan bahwa semakin rendah pendidikan ibu maka cenderung semakin rendah pula kesiapan ibu dalam mengaplikasikan toilet training pada anaknya.

Banyaknya anak yang bisa melakukan toilet training di Desa Tanjung Kecamatan Lamongan bisa disebabkan karena pendidikan orang tua sebagaian besar menengah dan mempunyai pekerjaan sebagai ibu rumah tangga dimana waktu yang diluangkan untuk mendidik toilet training juga lebih banyak.

3. Menganalisis hubungan pola asuh orang tua dengan tingkat keberhasilan toilet training pada anak usia 18-36 bulan di Desa Tanjung Kecamatan Lamongan Kabupaten Lamongan.

Dari hasil penelitian dapat diketahui bahwa dari 43 responden 21 anak yang bisa melakukan toilet training dan di dominasi ibu yang menerapkan pola asuh demokratis sebanyak 21 ibu. Sedangkan anak yang kurang bisa melakukan toilet training sebanyak 8 anak dan didominasi oleh ibu yang menerapkan pola asih permisif sebanyak 8 ibu. Dari analisis dengan menggunakan uji chi square diperoleh hasil terdapat hubungan yang signifikan antara hubungan pola asuh orang tua dengan tingkat keberhasilan toilet training pada anak usia 18-36 bulan.

Penerapan pola asuh permisif didasarkan pada perlindungan orang tua yang terlalu berlebihan pada anak, rasa khawatir berlebihan yang ditunjukkan oleh orang tua saat berpisah dengan anak berpotensi menimbulkan ketidakpercayaan diri pada anak pada saat menghadapi lingkungan baru. Perlindungan berlebihan dapat membuat anak kehilangan kreativitas dan menarik diri dari tantangan hidup. Selain itu perlindungan yang berlebihan membuat anak selalu diliputi kecemasan, merasa terancam, tidak berani mengambil keputusan dan tidak berani mengambil tanggung jawab. Oleh sebab itu pada hasil penelitian ini orang tua yang menerapkan pola asuh permisif memiliki kecenderungan anak menunjukkan respon kurang bisa dalam toilet training. Bila tidak ditangani hal ini dapat menghambat proses toilet training (Zaivera, 2008).

Menurut Subagyo (2010) bahwa proteksi berlebihan orang tua membuat anak menjadi ragu-ragu, tidak mampu berdiri sendiri, sangat bergantung pada orang lain dan mudah putus asa. Perilaku 
orang tua yang menggunakan pola asuh demokratis bilamana orang tua menunjukkan adanya kasih sayang, di sertai aturan-aturan dengan menetapkan batas dan kontrol yang mendukung anak pada tindakan konstruktif sehingga tercipta kemandirian pada anak. Anak tidak dibiarkan begitu saja tanpa kontrol orang tua, tetapi anak tidak begitu saja diatur terus-menerus sehingga anak sama sekali tidak mendapat kebebasan dalam tingkah laku. Dengan kata lain anak diberikan kebebasan untuk mengembangkan dirinya sepanjang ia dapat mempertanggung jawabkan. Sikap keterbukaan orang tua terhadap anak mendorong anak lebih mudah untuk mengungkapkan perasaannya terhadap sekitarnya termasuk saat berlatih toilet training sehingga toilet training menjadi lebih mudah. Oleh karena itu dalam penelitian ini orang tua yang menerapkan pola asuh demokratis memiliki kecenderungan anak menujukkan tingkat keberhasilan toilet training yang tinggi. Sedangkan untuk prilaku orang tua yang menggunakan pola asuh otoriter kecenderungan kendali berada sepenuhnya ditangan orang tua, semua peraturan dibuat orang tua dan harus dituruti oleh anak apapun yang terjadi sehingga anak menjadi tidak kreatif dan kurang berinisiatif dalam hidupnya.

\section{PENUTUP}

\section{Kesimpulan}

Berdasarkan penelitian yang dilakukan di Desa Tanjung Kecamatan Lamongan Kabupaten Lamongan dapat disimpulkan sebagai berikut:

1. Pola asuh orang tua di Desa Tanjung Kecamatan Lamongan Kabupaten Lamongan sebagian besar responden $(55,8 \%)$ memiliki pola asuh demokratis.

2. Tingkat keberhasilan toilet training anak usia 18-36 bulan di Desa Tanjung Kecamatan Lamongan Kabupaten Lamongan sebagian besar anak $(60,5 \%)$ bisa melakukan toilet training
3. Terdapat hubungan yang signifikan antara hubungan pola asuh orang tua dengan tingkat keberhasilan toilet training pada anak usia 18-36 bulan di Desa Tanjung Kecamatan Lamongan Kabupaten Lamongan

\section{Saran}

1. Bagi Tenaga Kesehatan

Diharapkan selalu memberikan pembinaan terhadap ibu yang mempunyai anak usia 18-36 bulan untuk melatih anaknya dalam toilet training dan penggunaan pola asuh yang tepat agar meningkatkan tingkat keberhasilan toilet training.

2. Bagi Orang Tua

Penelitian ini di harapkan dapat menambah pengetahuan tentang toilet training dan sikap serta pola asuh orang tua dalam menerapkan praktek toilet training.

\section{PUSTAKA}

Arikunto, S. 2006. Prosedur Penelitian Praktek. Jakarta: Rineka Cipta

Edward, D. 2006. Ketika Anak Sulit Diatur : Panduan Bagi Para Orang Tua Untuk Mengubah Masalah Perilaku Anak. Bandung : Kaifa PT.Mizan Pustaka

Fathi, B. (2011). Mendidik Anak Dengan Al Quran Sejak Janin. Jakarta : Grasindo

Gunarsa. 2008. Psikologi Praktis : Anak, Remaja dan Keluarga. Jakarta : PT. BPK Gunung Mulya

Hidayat, Aziz Alimul. 2007. Pengantar Ilmu Keperawatan Anak. Jakarta: Salemba Medika

Istichomah. 2009. Hubungan Tingkat Pengetahuan Ibu Asuh Dengan Pelaksanaan Toilet Training Secara Mandiri Pada Anak Usia Todler Di TPA Citra RSU Rajawali Citra Bantul. Suara Medika.

Juniati, Femilia. 2014. Perilaku Ibu Dalam Menyiapkan Toilet Training Pada 
Vol. 10 No. 2, Desember 2018

Anak Usia Toddler. Ponorogo : Universitas Muhammadiyah Ponorogo Maryunani, Anik. 2013. Asuhan Neonatus, Bayi, Balita \& Anak Pra Sekolah. Tajurhalang : In Media

Meggit, Carolyn. 2013. Memahami Perkembangan Anak (Agnes Theodora, Penerjemah). Jakarta : Indeks

Subagyo, dkk. 2010. Hubungan Antara Motivasi Stimulasi Toilet Training Oleh Ibu Dengan Keberhasilan Toilet Training Pada Anak Prasekolah. Suara Forikes

Supartini, Yupi. 2004. Buku Ajar Konsep Dasar Keperawatan Anak. Jakarta : EGC

Warner, Penny \& Paula Kelly. 2007. Mengajari Anak pergi ke toilet. Jakarta : Arcan

Wong, Donna L. 2009. Buku Ajar Keperawatan Pediatrik. EGC, Jakarta

Zaivera, Ferdinand. 2008. Mengenali dan Memahami Tumbuh Kembang Anak. Katahati, Jogjakarta 